\title{
EFEKTIVITAS LARUTAN MINUMAN PROBIOTIK YAKULT® DALAM MENURUNKAN JUMLAH CANDIDA ALBICANS PADA AKRILIK POLIMERISASI PANAS
}

\author{
Ria Koesoemawati \\ Bagian Prostodonsia, Fakultas Kedokteran Gigi, Universitas Mahasaraswati Denpasar \\ email :ria_kus@yahoo.com
}

\begin{abstract}
Using a removable denture can caused chronic inflammation commonly triggered from oral microorganism, specifically Candida albicans. The prevalence of denture stomatitis on removable denture user has been reported to be 15-70\%. Yakult ${ }^{\circledR}$ probiotic drink contains Lactobacillus casei Shirota that is known for its role in interfering the binding of pathogen microorganisms. The purpose of this study is to determined whether Yakult@ probiotic drink can decrease the number of Candida albicans on heat-cured acrylic resin plate. This study used pre-post test control group design method with $\mathrm{n}=25$, consisting of 5 groups. Acrylic plates are contaminated with Candida albicans and initial counting was conducted. Then the plates were immersed in Yakult ${ }^{\circledR}$ probiotic drinks on 15, 30, 60 minutes treatment groups and on Fittydent ${ }^{\circledR}$ and aquadest control groups. Afterwards the plantation and final counting were done. The result of the study is normally distributed and homogenous, then it was analyzed using Paired T-Test $(\mathrm{p}<0.05)$ with mean P1 12.20 \pm 4.38, P2 15.60 \pm 5.72 and P3 15.80 \pm 3.76 CFU/ml. LSD test shown significant differences between positive controls with all treatments and not significant differences between treatments. This study shows that probiotic Lactobacillus can inhibit the growth of Candida albicans. It can be concluded that Yakult ${ }$ probiotic drink can decrease the number of Candida albicans colonies on heat-cured acrylic resin plates immersion, with the most effective time being 60 minutes.
\end{abstract}

Keywords : heat-cured acrylic, Candida albicans, Yakult® probiotic drink.

\section{PENDAHULUAN}

Gigi tiruan lepasan merupakan salah satu gigi tiruan yang masih banyak digunakan untuk menggantikan gigi hilang. $95 \%$ gigi tiruan terbuat dari resin akrilik terutama polimethyl methacrylate merupakan bahan dasar gigi tiruan yang paling banyak digunakan karena estetika yang sangat baik, pemrosesan mudah, tidak bersifat toksik, tidak mengiritasi jaringan, dapat diperbaiki dan lebih ekonomis. ${ }^{1,2}$

Pemakaian gigi tiruan lepasan dapat menyebabkan inflamasi kronik pada mukosa rongga mulut, khususnya pada bagian palatal dan mukosa gingiva yang berkontak langsung dengan basis gigi tiruan atau biasa dikenal dengan denture stomatitis. ${ }^{3}$ Denture stomatitis mengenai $35-50 \%$ orang yang menggunakan gigi tiruan lengkap. ${ }^{4}$ Dari studi epidemiologi yang telah dilaporkan, menyebutkan bahwa prevalensi denture stomatitis pada pengguna gigi tiruan sekitar $15-70 \% .^{5}$

Denture stomatitis terjadi akibat adanya adhesi Candida albicans ke permukaan mulut. Denture stomatitis bukan hanya terjadi akibat adanya aktifitas dari Candida albicans saja, melainkan merupakan hasil biofilm dari multispesies yaitu terdapat pula bakteri Streptococcus mutans. ${ }^{6}$

Pencegahan denture stomatitis yaitu dengan pembersihan gigi tiruan secara berkala. Ada dua metode dalam pembersihan gigi tiruan, secara mekanis yaitu pembersih abrasif dengan penggunaan sikat dan pasta gigi serta secara kimiawi seperti hipoklorit, zat oksigenasi dan asam lemah. Denture cleanser termasuk secara kimiawi memiliki lebih banyak keuntungan, seperti efektif dalam menghilangkan mikroba pada gigi tiruan, pembersihan secara menyeluruh, kerusakan akibat pembersihan dapat diminimalisir dan mudah digunakan khususnya untuk pasien yang memiliki keterbatasan. $^{7}$

Denture Cleanser dirancang untuk menghilangkan noda, deposit, dan debris dari permukaan protesa gigi tiruan. Denture Cleanser yang ideal harus mudah digunakan, menghilangkan secara efektif bahan organik dan anorganik dari permukaan gigi tiruan, memiliki sifat bakterisida dan fungisida, dan kompatibel dengan semua bahan dasar gigi tiruan. Denture Cleanser secara kimia memiliki keuntungan yaitu mudah digunakan, dan telah menunjukkan keefektifannya dalam mengurangi pembentukan biofilm secara in vitro. ${ }^{8}$

Denture cleanser gigi tiruan yang sering beredar dipasaran seperti fittydent ${ }^{\circledR}$ masih tergolong mahal dan sulit ditemukan. Ada berbagai bahan alternatif yang dapat digunakan untuk menghambat pertumbuhan jamur dan bakteri, salah satunya dengan probiotik. Menurut WHO probiotik merupakan organisme hidup yang mampu memberikan efek yang menguntungkan untuk hostnya apabila digunakan dalam takaran yang cukup. ${ }^{9}$

Resin Akrilik

Bahan resin akrilik yang paling sering dipakai di bidang kedokteran gigi sebagai basis gigi tiruan 
adalah Heat-Cured Acrylic (resin akrilik polimerisasi panas), dimana aktivatornya adalah panas. ${ }^{10}$ Keuntungan bahan ini ialah estetik baik karena warna menyerupai jaringan gusi, translusen, harga relatif murah, manipulasi mudah, tidak larut dan tidak aktif dalam cairan mulut, mudah direparasi dan perubahan dimensinya kecil,tahan terhadap daya pertumbuhan bakteri, mempunyai berat yang ringan. ${ }^{11}$

Basis gigi tiruan dibagi menjadi 2 permukaan yaitu bagian yang dipoles yang menghadap ke lidah dan yang menghadap ke mukosa mulut. Pada penelitian ini digunakan basis resin akrilik yang tidak dipoles karena bagian tersebut menutupi mukosa oleh basis gigi tiruan yang dapat mengurangi efek pembersihan oleh saliva, yang mengakibatkan sisa makanan dan mikroorganisme menumpuk. ${ }^{12}$

\section{Candida Albicans}

Candida albicans disebut sebagai agen infeksius oportunistik yang dapat berubah menjadi patogen. Perubahan ini disebabkan karena adanya perubahan kondisi di rongga mulut. Salah satunya adalah pemakaian gigi tiruan. Berdasarkan suatu penelitian, Candida albicans dapat diisolasi sebanyak $86 \%$ dari penderita denture stomatitis, bila dibandingkan dengan Staphylococcus aureus 84\%, dan Streptococcus mutans sebanyak 16\%. Hal ini menunjukkan bahwa Candida albicans adalah mikroorganisme utama dalam terjadinya denture stomatitis. ${ }^{13}$ Selain itu Candida albicans lebih sering ditemukan pada plak gigi tiruan dibandingkan pada plak gigi. Plak gigi tiruan dapat didefinisikan sebagai biofilm yang terbentuk pada gigi tiruan dan terdapat mikroorganisme. $^{14}$

Gigi tiruan tanpa pembersihan dapat menyebabkan akumulasi plak karena adanya permukaan resin akrilik yang kasar, selanjutnya terjadi adesi antara Candida albicans dengan gigi tiruan. ${ }^{15}$

\section{Probiotik}

Probiotik bisa berupa bakteri, jamur, atau ragi, tetapi mayoritas probiotik adalah bakteri. Jenis strain yang paling umum digunakan dalam pembuatan probiotik adalah Lactobacillus dan Bifidobacterium. ${ }^{16}$ Probiotik memiliki banyak pengaruh positif dalam menciptakan kesehatan mulut yang lebih baik. Pada dasarnya probiotik membantu dalam mengikat mikroorganisme mulut dengan protein dan formasi biofilm. Melalui interaksi langsungnya, probiotik bersaing dengan mikroorganisme oral yang ada. Probiotik menghasilkan bahan kimia untuk menghambat bakteri oral yang dapat merusak kebersihan mulut. Interaksi tidak langsung probiotik efektif dalam proses menghilangkan bakteri patogem dan menstabilkan kondisi normal. Probiotik memodulasi dan mensistematisasi fungsi kekebalan tubuh pada mekanisme pertahanan jaringan setempat. ${ }^{17}$

Dari uraian di atas, maka tujuan penelitian ini adalah untuk mengetahui apakah larutan minuman probiotik Yakult巴 dapat menurunkan jumlah koloni Candida albicans secara efektif pada plat resin akrilik polimerisasi panas. Dengan demikian diharapkan minuman probiotik Yakult® dapat digunakan sebagai salah satu larutan yang berfungsi sebagai desinfektan pada gigi tiruan lepasan.

\section{BAHAN DAN METODE}

Pembuatan sampel plat resin akrikik yaitu diameter model malam 10X10X2 mm, ${ }^{18}$ dilakukan penanaman model malam dalam cuvet, diisi dengan resin akrikik polimerisasi panas, direbus selama 120 menit, kemudian dirapikan dengan tidak dipoles. Didapatkan sediaan plat resin akrilik sebanyak 25 lempemg $(\mathrm{n}=25)$.

Pembuatan suspensi Candida albians diambil dari stok laboratorium Mikrobiologi Unair Surabaya, dengan cara diambil 1 ose dimasukkan pada media Saboraud broth volume $5 \mathrm{ml}$, diinkubasi 48 jam suhu $37^{\circ} \mathrm{C}$. Di proses sampai didapatkan sesuai standart larutan $10^{8}$ Mc Farland. Tahapan selanjutnya dibuat suspensi fungi $10^{8} \mathrm{CFU} / \mathrm{ml}$, suspensi inilah yang digunakan untuk kontaminasi pada plat resin akrilik.

Penghitungan jumlah Candida albicans pada plat resin akrilik diawali dengan plat resin akrilik dicuci dengan air mengalir selama 48 jam untuk mengurangi sisa monomer kemudian disterilkan menggunakan autoclave $121^{\circ} \mathrm{C}$ selama 15 menit. Langkah selanjutnya plat resin akrilik direndam dalam saliva steril selama 1 jam, kemudian dibilas dengan PBS 2 kali. Plat resin akrilik dimasukkan kedalam tabung reaksi yang berisi suspensi Candida albicans (setelah inkubasi 24 jam), kemudian diinkubasi lagi selama 24 jam pada suhu $37^{\circ} \mathrm{C}$. Penghitungan awal jumlah koloni Candida albicans dalam pengukuran Colony Forming Unit Permililiter (CFU/ml).

Plat resin akrilik dibagi menjadi lima kelompok. Tiga kelompok dimasukkan ke dalam tabung reaksi tertutup dengan masing-masing berisi larutan minuman probiotik Yakult@. Lama perendaman yang dipergunakan adalah 15 menit, 30 menit dan 60 menit. Pada kelompok kontrol positif, dimasukkan dalam tabung reaksi tertutup berisi larutan fittydent ${ }^{\circledR}$ dalam waktu 30 menit, sedangkan pada kelompok kontrol negatif digunakan aquades steril dengan waktu yang sama.

Plat resin akrilik yang direndam dalam masing-masing bahan, dibilas dengan PBS 2 kali, kemudian dimasukkan ke dalam $10 \mathrm{ml}$ Saboraud broth, selanjutnya dilakukan vibrasi dengan vortex pada semua tabung reaksi selama 30 detik untuk melepaskan Candida albicans yang melekat pada lempeng. Mengambil $0,1 \mathrm{ml}$ suspensi Candida albicans dimasukkan ke dalam Sabouraud's dextrose agar, dilakukan spreading diinkubasi selama 48 jam pada suhu $37^{\circ} \mathrm{C}$. Terakhir menghitung jumlah koloni Candida albicans dalam pengukuran Colony Forming Unit Permililiter (CFU/ml).

Analisis data dengan Uji Paired T-Test digunakan untuk melihat perbedaan dari beberapa varian sebelum dan sesudah perlakuan. Untuk uji beda lanjut dari masing-masing kelompok menggunakan Uji (post-hoc test) Least Significant Difference test (LSD). 


\section{HASIL DAN PEMBAHASAN}

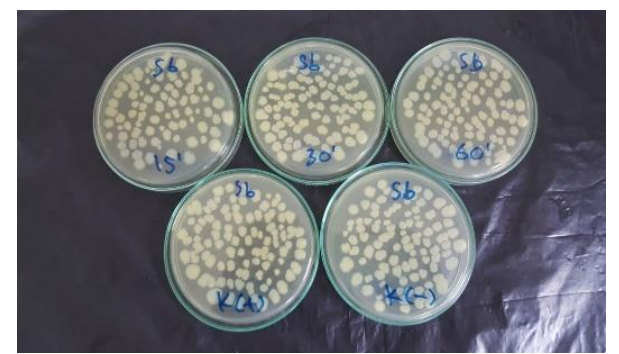

Gambar 1. Jumlah koloni Candida albicans dalam media Sabouraud,s dextrose agar, sebelum dilakukan perlakuan dengan larutan minuman probiotik Yakult ${ }^{\circledR}$

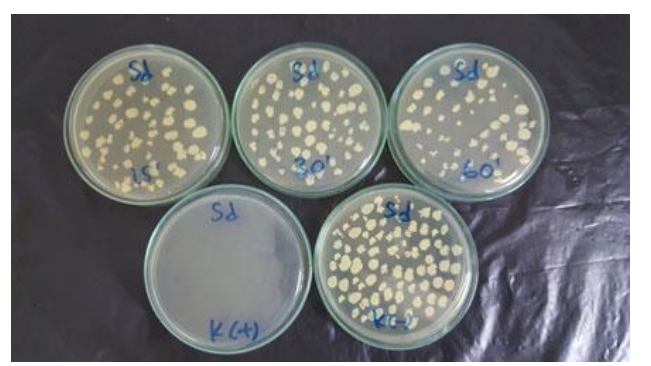

Gambar 2. Jumlah koloni Candida albicans dalam media Sabouraud,s dextrose agar, setelah dilakukan perlakuan dengan larutan minuman probiotik Yakult ${ }^{\circledR}$ selama 15 menit, 30 menit, 60 menit

Hasil Uji Normalitas Data dengan menggunakan Uji Shapiro-Wilk diperoleh nilai signifikansi $(p>0,05)$ sehingga dapat dijelaskan bahwa data berdistribusi normal. Hasil Uji Homogenitas Data dengan Levene's test nilai signifikansi ( $p>0,05)$, hal ini menunjukkan bahwa data bersifat homogen.

Analisis efek perlakuan diuji menggunakan Paired T-Test dengan sigfinikansi $\quad(\mathrm{p}<0,05)$ berdasarkan rerata jumlah koloni Candida albicans antar kelompok sebelum dan sesudah diberikan perlakuan berupa perendaman dalam larutan minuman probiotik Yakult®, dapat dilihat pada tabel 1.

Tabel 1. Hasil Uji Perbedaan Rerata Koloni Candida albicans Antar Kelompok Sebelum dan Sesudah Dilakukan Perendaman dengan Larutan Minuman Probiotik Yakult $(\mathrm{n}=5)$.

\begin{tabular}{cccrc}
\hline Kelompok & Rerata & SB & t & p \\
\hline & & & & \\
\hline P 1 (15mnt) & 12,200 & 4,381 & 6,226 & 0,003 \\
P 2 (30mnt) & 15,600 & 5,727 & 6,091 & 0,004 \\
P 3 (60mnt) & 15,800 & 5,768 & 9,376 & 0,001 \\
K + (Fittydent) & 119,800 & 4,266 & 62,792 & 0,000 \\
K - (aquades) & 3,800 & 10,059 & 0,845 & 0,446 \\
\hline
\end{tabular}

Hasil pada Tabel 1, menunjukkan bahwa rerata jumlah koloni Candida albicans dengan Uji Paired T-Test dengan membandingkan sebelum dan sesudah perlakuan, didapatkan pada kelompok perlakuan 15, 30, 60 menit dan kelompok kontrol Fittydent ${ }^{\circledR}$ terjadi perbedaan bermakna $(\mathrm{p}<0,05)$, sedangkan pada kelompok kontrol aquades tidak berbeda bermakna ( $>00.05)$. Hal ini berarti jumlah koloni Candida albicans pada plat resin akrilik sebelum dan sesudah perlakuan serta pada kontrol positif hasilnya berbeda bermakna.

Hasil penelitian ini menunjukkan bahwa plat resin akrilik yang direndam dalam larutan minuman probiotik Yakult® selama 15，30 dan 60 menit mempunyai kemampuan dapat menurunkan pertumbuhan koloni Candida albicans, demikian pula pada perendaman dengan Fittydent $\AA^{\circledR}$. Hal ini disebabkan karena larutan minuman probiotik Yakult ${ }^{\circledR}$ memiliki kandungan probiotik Lactobacillus Casei Shirota yang memiliki peran sebagai antibakteri, dan anti jamur. Penelitian ini juga sesuai dengan hasil penelitian sebelumnya yang menganalisis peran probiotik dengan jenis Lactobacili dalam menghambat pertumbuhan Streptococcus mutans dan Candida albicans. ${ }^{19}$

Dapat dijelaskan bahwa mekanisme kerja Lactobacillus casei shirota pada Yakult $\circledast$ memiliki bakteriosin berupa caseicin, lactacin $B$, lactacin $F$ dan bahan-bahan lain berupa asam laktat dan $\mathrm{H}_{2} \mathrm{O}_{2}$. Mekanisme kerja bakteriosin terhadap jamur sama halnya dengan mekanisme bakteriosin terhadap bakteri. ${ }^{20}$ Target kerja bakteriosin adalah membran sitoplasma sel Candida albicans, dimana reaksi awal adalah merusak permeabilitas membran dan menghambat produksi energi, biosintesis protein dan asam nukleat. Kontak antara bakteriosin dengan membran sel mengakibatkan gangguan potensial membran berupa distabilitas membran sitoplasma, sehingga sel menjadi tidak kuat, ketidakstabilan ini memberikan dampak berupa pembentukan lubang atau pori pada sel, sehingga terjadi kebocoran pada membran sitoplasma, yang memberikan efek berupa pertumbuhan sel yang terhambat atau mati. ${ }^{21}$

Mekanisme probiotik yang lain adalah dengan cara, probiotik berkompetisi dengan mikroorganisme patogen mencari tempat perlekatan dan beragregrasi. Keadaan ini akan menghambat adhesi mikroorganisme patogen dan menguranginya. Cara kerja probiotik yang lain adalah menghambat mikroorganisme patogen memproduksi pro-inflammatory cytokine, serta mengurangi produksi MMP, sehingga terjadi pengurangan inflamasi dan kerusakan jaringan. ${ }^{16}$

Untuk mengetahui Uji Beda lanjut pada masing-masing kelompok dilakukan dengan Least Significant Difference - test (LSD). Hasil uji disajikan di Tabel 2 berikut :

Tabel 2. Hasil Uji Beda Nyata Terkecil Jumlah Koloni Candida albicans Sesudah Diberikan Perlakuan Perendaman Larutan Minuman Probiotik Yakult® Antar Kelompok ( $\mathrm{n}=5)$.

\begin{tabular}{llcc}
\hline \multicolumn{2}{l}{ Kelompok } & Beda Rerata $(\mathbf{C F U} / \mathbf{m l})$ & $\mathbf{p}$ \\
\hline $\mathrm{K}+$ dan & P 1 & 108,8 & 0,000 \\
& P 2 & 107,4 & 0,000 \\
& P 3 & 106,8 & 0,000 \\
P 1 dan & P 2 & 1,4 & 0,621 \\
& P 3 & 2,0 & 0,482 \\
P 2 dan & P 3 & 0,6 & 0,832 \\
\hline
\end{tabular}


Berdasarkan uji lanjutan dengan Least Significant Difference - test (LSD) dengan signifikansi $(\mathrm{p}<0,05)$ didapatkan hasil signifikan beda pada kontrol positif terhadap ketiga perlakuan. Sementara antar perlakuan, semua tidak beda signifikan $(\mathrm{p}>0,05)$.

Hasil uji Least Significant Difference - test (LSD) menunjukkan bahwa pada Candida albicans, kelompok kontrol positif dalam hal ini fittydent ${ }^{\circledR}$ mempunyai perbedaan signifikan dengan larutan minuman probiotik Yakult@. Hal ini karena fittydent ${ }^{\circledR}$ mengandung citric acid. Zat ini digunakan sebagai pembersih dan anti oksidan. Citric acid berperan sebagai agen chemotherapeutic yang dapat menghancurkan biofilm melalui mekanisme ion kalsium. Mekanisme ini menyebabkan citric acid merusak calcium bridges dan kemudian merusak matrix biofilm sehingga terjadi aktivitas antibiofilm. ${ }^{22}$ Selain itu fittydent $₫$ juga mengandung sodium perborate yang bersifat antiseptik dan berfungsi sebagai desinfektan. ${ }^{23}$ Perlu diperhatikan efek perendaman gigi tiruan secara terus-menerus dalam larutan fittydent ${ }^{\circledR}$ dapat menyebabkan perubahan warna, menurunkan kekerasan resin dan kekasaran permukaan basis gigi tiruan karena tingginya konsentrasi bahan pembersih. $^{24}$

Hasil Uji LSD pada antar perlakuan tidak beda signifikan, tetapi dari beda rerata antar perlakuan menunjukkan hasil yang makin menurun. Hal ini dapat dijelaskan karena probiotik hanya mengandung mikroorganisme dan tidak ada bahan lain sebagai larutan pembersih gigi seperti fittydent $\AA$. Selain itu probiotik dengan cara kerjanya tersebut lebih utama untuk menghambat pertumbuhan bakteri Streptococcus mutans dibanding Candida albicans. Ini juga sesuai dengan hasil penelitian Wagner yang menyatakan bahwa bakteri probiotik memerlukan waktu lebih lama dalam membunuh jamur Candida albicans.dibanding dengan bakteri. $^{25}$

Pada penelitian ini didapatkan bahwa pada perlakuan dengan larutan minuman probiotik Yakult ${ }^{\circledR}$ dengan waktu perendaman plat resin akrilik selama 60 menit dapat menurunkan jumlah koloni Candida albicans lebih besar dibandingkan waktu prendaman plat selama 30 menit maupun 15 menit. Terlihat bahwa bertambahnya waktu perendaman, menunjukan jumlah koloni Candida albicans semakin menurun. Hasil tersebut sesuai dengan pendapat Jawets bahwa daya kerja antimikroba tergantung dari konsentrasi bahan antiseptik, waktu dan suhu. ${ }^{26}$

\section{SIMPULAN}

Berdasarkan hasil penelitian dan pembahasan di atas didapatkan simpulan bahwa plat resin akrilik polimerisasi panas yang direndam dalam larutan minuman probiotik Yakult@ teruji efektif dapat menurunkan jumlah koloni Candida albicans dengan semakin lama waktu perendaman, semakin dapat menurunkan jumlah koloni Candida albicans, Dalam penelitian ini waktu yang paling efektif adalah 60 menit. Perbedaan hasil efektifitas denture cleanser Fittydent ${ }^{\circledR}$ dengan probiotik Yakult ${ }^{\circledR}$ disebabkan dari isi kandungan dan mekanisme kerjanya.

\section{DAFTAR PUSTAKA}

1. Craig RG, Powers. Dental Materials, Properties and Manipulation. USA: Elsevier; 2004. h. 330-2.

2. Nandal S, Ghalaut,P, Shekhawat H, Gulati MS. New era in denture base resin : A Review. Dental Journal of Advance Studies 2013; 1(3): 136-43.

3. Baskaran, Kaviena. Denture Stomatitis. IJSR 2015; 6(5): 56-61.

4. Maller US, Karthik KS, Maller,SV. Candidiasis in denture wearers : A Literature Review. JIADS 2010; 1: 27-30.

5. Gendreau L, Loewy Z. Epidemiology and etiology of denture stomatitis. Journal of Prosthodontics 2011; 20: 251-60.

6. Vasconcelos LC, Sampaio FC, Carméli M, Pereira MS, Peixoto MH. Streptococcus mutans in denture stomatitis patients under antifungal therapy. Rev. odonto ciên 2010; 25(21): 120-5.

7. Rueggeberg, Fred. Denture Materials for Completes Dentures, Dalam Textbook of Complete Denture. $6^{\text {th }}$ ed. USA: PMPH; 2009

8. Gajwani-Jain S, Magdum D, Karagir A, Pharane P. Denture cleansers : A Review. IOSR Journal of Dental and Medical Sciences 2015; 14(2): 94-6.

9. Bhushan J, Chachra S. Probiotic-their role in prevention of dental caries. J Oral Health Comm Dent 2010; 4(3): 78-82.

10. Anusavice KJ, Shen C, Rawls HR. 2013, Philip's Science of Dental Materials. $12^{\text {th }}$ ed. Missouri: Elsevier Saunders; 2013: 107,475-8, 483-5.

11. Walls, McCabe JF. Applied Dental Materials. $9^{\text {th }}$ ed. Munksgaard: Blackwell; 2008: 110

12. Cakan U, Kara O, Kara H. Effects of various denture cleansers on surface roughness of hard permanent reline resins. Dental Materials Journal 2015; 3(2): 246-51.

13. Monroy TB, Victor MM, Fernando FM, Beatriz AB, Guillermo Q, Luis OS. Candida albicans, Staphylococcus aureus and Streptococcus mutans colonization in patients wearing dental prosthesis. Med Oral Patol Oral Cir Bucal 2005; 10: 27-39.

14. Serefko, Anna D, Poleszak, Ewa J, Malm, Anna. Candida albicans denture biofilm and its clinical significance. Polish Journal of Microbiology 2012; 61(3): 161-7.

15. Salerno C, Pascale M, Cantaldo M, Esposito V, Busciolano M, Milillo L, Guida A, Petruzzi M. Candida-associated denture stomatitis. Med Oral Patol Oral Cir Bucal 2011; 16(2): 139-43.

16. Haukioja A. Probiotic and oral health. Eur Journal of Dent 2010; 4: 348-55.

17. Reddy V, Prasad A, Mohan G. Probiotic Lactobacilli and oral health. Journal of Prosthodontic India 2011; 3(2): 100-3.

18. Thippeswamy HM, Kumar, Nanditha, Swamy, Raghavendra, Gujjari, Anil K. Efficacy of commercial and household denture cleansers against Candida albicans adherent to acrylic denture base resin: An in vitro study. Indian Journal of Dental Research 2012; 23(1): 39-42.

19. Keller MK, Hasslöf P, Stecksen-Blicks C, Twetman S. Co-aggregation and growth inhibition of 
probiotic Lactobacilli and clinical isolates of Mutans streptococci: An In Vitro Study. Acta Odontol Scan 2011; 69(5): 263-68.

20. Parada JL, Caron CR, Medeiros AD, Soccol CR. Bacteriocins from lactic acid bacteria: purification, properties and use as biopreservatives. Braz Arch Biol Tech 2007; 50: 521-42.

21. Winarsa R. Daya kerja filtrat biakan hidup Lactobacillus casei subspecies Shirota terhadap pertumbuhan Salmonella thypimurium, Shigella flexneri dan Eschericia coli in vitro, [Tesis], Surabaya: Universitas Airlangga, Indonesian. 1999

22. Foat F, Cavalcanti YW, Bertolini MDME, Pinto LDR, Silva WJDS, Cury AADB. Efficacy of citric acid denture cleanser on the Candida Albicans biofilm formed on poly (methyl methacrylate): effects on residual biofilm and recolonization process. Biomed Central Oral Health 2014; 14(77): $1-7$.
23. Pisani, Marina-Xavier, Leite,, Fagundes VM, Badaró, Malheiros M. Soft denture liners and sodium perborate: sorption, solubility and color change. Braz. J. Oral Sci. 2015; 14(3): 219-223.

24. Porwal A, Khandelwal M, Punia V, Sharma V. 2016. Effect of denture cleansers on color stability, surface roughness and hardness of different denture Bbse Resins', JIPS, 2016vol. 17, no.1, hlm 61-7

25. Wagner RD, Pierson C, Warner T, Dohnalek M, Hilty M, Balish E. Probiotic effects of feeding heat-killed Lactobacillus acidophilus and Lactobacillus case i to Candida albicans-colonized immunodeficient Mice. J Food Prot. 2000; 63(5): 638-44.

26. Jawetz E, Melnick J L, Adelberg EA. Mikrobiologi Kedokteran. Edisi ke-20, EGC. Jakarta; Penerbit Buku Kedokteran. 1996. H. 213 